\title{
Infections in Hospitalised Patients with Multiple Myeloma: Main Characteristics and Risk Factors
}

\section{Hastanede Tedavi Gören Multipl Miyelom Hastalarında Görülen Enfeksiyonlar: Temel Özellikler ve Risk Faktörleri}

\author{
Toni Valković1, Vedrana Gačić2 , Jelena Ivandić3, Božo Petrov4, Renata Dobrila-Dintinjana5, \\ Elizabeta Dadić-Hero6, Antica Načinović-Duletićl \\ ${ }^{1}$ University Hospital Centre Rijeka, Clinic of Haematology, Rijeka, Croatia \\ ${ }^{2}$ University Hospital Mostar, Clinic of Haematology, Mostar, Bosnia and Herzegovina \\ ${ }^{3}$ University Hospital Centre Rijeka, Clinic of Gynaecology and Obstetrics, Rijeka, Croatia \\ ${ }^{4}$ University Hospital Mostar, Clinic of Psychiatry, Mostar, Bosnia and Herzegovina \\ 5 University Hospital Centre Rijeka, Clinic of Oncology and Radiotherapy, Rijeka, Croatia \\ ${ }^{6}$ Community Primary Health Centre, Primorsko-Goranska County, Rijeka, Croatia
}

\begin{abstract}
:
Objective: Multiple myeloma is a common haematological malignancy and immune dysfunction is the hallmark of the disease. It leads to an increased infection risk, which is still a major cause of mortality. The infection spectrum and characteristics have evolved with the introduction of novel agents. An understanding of risk factors that increase susceptibility to infections is critical in fighting them. This retrospective investigation aimed to establish the incidence and main characteristics of infections in non-transplanted hospitalised myeloma patients in our department over a 3-year period, as well as factors associated with infections.

Materials and Methods: A total of 240 hospitalised patients with multiple myeloma (120 males and 120 females; average age: 69 years, range: 41-89 years) who were diagnosed or treated in our department from January 2008 to December 2010 were included in this study and their data were retrospectively analysed.

Results: Infections were identified in $17.9 \%$ of hospitalised patients. The most common pathogen found was Pseudomonas aeruginosa. The frequency of gram-positive and gram-negative pathogens was similar. In $37.2 \%$ of cases, the agent was not isolated. The most common sites of infections were the urinary system and the blood (septicemia). The frequency of infection increased with duration of disease and the rate of reinfection was $41.9 \%$. The patients treated with bortezomib had the highest infection occurrence. Fatal outcome occurred in $9.3 \%$ of cases.

Conclusion: The factors associated with infections in this investigation were female sex, 3B clinical stage of disease, increased serum creatinine and ferritin levels, neutropenia, poor general condition, and presence of catheters. Myeloma patients with one or more of these mentioned risk factors should be monitored with particular care in order to decrease the incidence and severity of infective complications.
\end{abstract}

Key Words: Multiple myeloma, Infections, Risk factors, Therapy

Address for Correspondence: Jelena IVANDIĆ, M.D.,

University Hospital Centre Rijeka, Clinic of Gynaecology and Obstetrics, Rijeka, Croatia

Phone: +0038551421426 E-mail: jelenaivandic@yahoo.com

Received/Geliş tarihi : May 16, 2013

Accepted/Kabul tarihi : February 21, 2014 


\section{Özet:}

Amaç: Multipl miyelom, sık görülen bir hematolojik malignite olup, bağışıklık sistemi disfonksiyonu bu hastalı̆̆ın en belirgin özelliğidir. Bu hastalığın sebep olduğu ileri düzeyde enfeksiyon riski hala başlıca ölüm sebebidir. Enfeksiyonun spektrumu ve özellikleri, yeni geliştirilen ajanlarla birlikte değişiklik göstermektedir. Enfeksiyonlara hassasiyeti arttıran risk faktörlerinin anlaşılması, bu enfeksiyonlara karşı savaşmak için son derece önemlidir. Bu retrospektif çalışma neticesinde 3 yıldır departmanımızda yatırılarak tedavi gören ve transplantasyon yapılmamış miyelom hastalarımızda görülen enfeksiyonların temel özelliklerinin saptanması amaçlanmıştır.

Gereç ve Yöntemler: Ocak 2008 ile Aralık 2010 tarihleri arasında departmanımızda tanısı konmuş ve tedavi görmüş toplam 240 multipl miyelom hastası (120 erkek ve 120 kadın; ortalama yaş: 69, yaş aralığı: 41-89) bu çalışmaya dahil edilmiştir ve bu hastalardan elde edilen veriler retrospektif olarak incelenmiştir.

Bulgular: Hastanemizde yatan hastaların \%17,9'unda enfeksiyona rastlandı. En sık görülen patojenin Pseudomonas aeruginosa olduğu saptandı. Gram pozitif ve gram negatif patojenlerin sıklığı aynıydı. Olguların \%37,2'sinde ajan izole edilemedi. Enfeksiyon kaynağının sıklıkla üriner sistem ve kan olduğu görüldü. Hastalık süresince enfeksiyon oranının arttığı ve reenfeksiyon sıklığının \% 41,9 olduğu tespit edildi. En sık enfeksiyon bortezomib ile tedavi edilen hastalarda görüldü. Olguların \%9,3'ü ölümle sonuçlandı. Sonuç: Bu çalışmada enfeksiyonlarla ilişkilendirilen faktörler kadın cinsiyet, ileri evre (III 3B) hastalık, artmış serum kreatinin ve ferritin düzeyi, nötropeni, genel durumun bozukluğu ve kateterlerin varlığıdı. Bahsi geçen bu faktörlerden bir ya da ikisine sahip miyelom hastalarda görülebilecek enfektif komplikasyon oranını ve şiddetini düşürmek amacıyla hastaların özenli ve dikkatli bir bakımla izlenmesi gerekmektedir.

Anahtar Sözcükler: Multipl miyelom, Enfeksiyonlar, Risk faktörleri, Tedavi

\section{Introduction}

Multiple myeloma (MM) is a common haematological malignancy, and immune dysfunction is one of the hallmarks of the disease. The disease-related immunological defects, as well as therapy-related immunosuppression, lead to the increased risk of infective complications, which are a major cause of mortality.

Malignant plasma cells produce monoclonal paraprotein, which is non-functional and crowds out the polyclonal immunoglobulins. Hypogammaglobulinaemia, which is related to suppression of CD19+ B lymphocytes, exists in a great majority of patients with the active disease [1]. Besides hypogammaglobulinaemia, numerous immunological abnormalities have been observed, such as several defects of T lymphocytes, dendritic cells, natural killer cells, and the complement cascade $[2,3,4,5,6,7]$. Quantitative and qualitative disorders of neutrophils are related to myelosuppressive therapy or bone marrow infiltration $[8,9]$. Furthermore, several other risk factors increase susceptibility to infections in MM, such as renal failure, smoking, using of various catheters, vertebral collapse, iron overload, or use of opiate drugs $[10,11]$.

The spectrum and characteristics of infective complications in myeloma patients have evolved with the introduction of autologous and allogeneic hematopoietic stem cell transplant (HSCT) or different novel drugs, which together cause an increasing susceptibility to fungal and viral infections $[12,13,14,15]$.
The present study has analysed the frequency and characteristics of infective complications, as well as factors related to risk for infections, in the myeloma patients treated at our institution over a 3-year period.

\section{Materials and Methods}

Retrospectively, using hospital medical documentation, 240 cases of hospitalised patients with MM (120 males and 120 females; average age of 69 , range of 41-89 years) who were diagnosed or treated in our department from January 2008 to December 2010 were processed. Because the majority of patients were hospitalised more than once, the total number of our cases was larger than the number of patients included in this study ( 37 males and 35 females, respectively). Only patients who were not treated at the time of this study with high-dosage therapy and HSCT were included. The diagnosis was established according to International Myeloma Working Group criteria [16]. The great majority of patients in this study had IgG, IgA, or a light chain myeloma; however, 1 patient with $\operatorname{IgD}$ and 1 patient with nonsecretory myeloma were also included. Our patients were treated fairly uniformly. VAD (vincristine, doxorubicin, and dexamethasone) and MP (oral melphalan and prednisone) regimens were mostly used as the induction therapy (according to the patient's age and eligibility for high-dose therapy), with thalidomide-based protocols as second-line therapy and bortezomib-based protocols as third- or next-line therapy. Monotherapy with dexamethasone was used as a front-line therapy, as well as for postinduction protocol in some patients. 
The study was approved by the Medical School of Rijeka Ethics Committee.

The criteria for infection used in our study were increased body temperature above the normal range $\left(37^{\circ} \mathrm{C}\right)$ or isolation of a microbial agent in patients who also had concomitant clinical symptoms and/or humoral signs of infections (leukocytosis, neutrophilia, marked "left shift", or increased $\mathrm{C}$ reactive protein in comparison with a baseline value).

The frequency and the basic characteristics of the identified infections, such as type of isolated microbial agents, site of infection, time of occurrence and outcome of infection, rate of re-infections, and type of antitumor therapy at the time of infection, were also determined. The factors that could influence the pathogenesis and incidence of infections, including sex, WHO/ECOG performance status [17], DurieSalmon stage of disease [18], International Staging System (ISS) score [19], serum creatinine level, immuneparesis defined qualitatively (decreased serum concentration of any polyclonal immunoglobulin class), neutropenia (defined as blood neutrophil count of $\leq 2 \times 10^{9} / \mathrm{L}$ ), serum ferritin level, and presence of any catheters, were compared and statistically analysed in cases with and without infections $[17,18,19]$. All these parameters according to the occurrence of infections are listed in Table 1.

\section{Statistical Analysis}

Data were expressed as means \pm standard deviations, with the sample size (n). Nominal and ordinal variables were analysed with the chi-square test. Normality of distribution of continuous variables was tested by the Kolmogorov-Smirnov test. For continuous variables with distribution significantly different from the norm, we used the median and interquartile range, and the differences between the groups for these variables were tested with the Kruskal-Wallis test and MannWhitney U test. In the symmetric distribution of continuous variables, to display the mean values and dispersion measures, we used the arithmetic mean and standard deviation, and their comparison was done with Student's t-test. SPSS for Windows (version 17.0, SPSS Inc., Chicago, IL, USA) and Apache OpenOffice (version 3.3.0, The Apache Software Foundation, Wilmington, DE, USA) were used for statistical analyses. The values were considered statistically significant at $\mathrm{p}<0.05$ (2-tailed).

\section{Results}

Infections were identified in 43 out of 240 (17.9\%) hospitalised patients. In 27 (62.8\%) cases of infection, the microbial agent was identified, while in $16(37.2 \%)$ cases, no isolation was possible. The most common pathogen found was Pseudomonas aeruginosa. The frequency of gram-positive and gram-negative bacteria was almost the same. In 10 out of
27 cases, more than 1 microorganism was isolated (in 9 cases 2 and in 1 case 3 agents were isolated at the same time). In all cases, the identified microorganisms were bacteria, without any proven viral or fungal isolates. The frequencies of isolated agents are shown in Table 2.

The most common sites of infections were the urinary system in 16 cases (37.2\%) and the blood in 7 cases (16.3\%). In 4 cases more than 1 site of infection was found (urinary system and blood, as well as upper respiratory tract and blood, both in 2 cases). In $8 / 43$ cases (18.6\%), the site of infection was not identified. The determined sites of infection are summarised in Table 3. The average age in the group of patients with infections was 69 years and in those without infections was 65 years, which did not reach statistical significance $(\mathrm{p}=0.094)$.

The average disease duration in the cases without infection was 17.7 months and in the cases with infection was 33.6 months, which was statistically significant $(\mathrm{p}=0.004)$.

In 18 of 43 cases, infections occurred in patients who had previously suffered from infective complication, which means that the re-infection rate was $41.9 \%$. Fatal outcome related to infection occurred in $4 / 43$ cases (9.3\%).

According to the type of therapy, the highest frequency of infections occurred in the group treated with bortezomib (14/28) and the lowest with VAD protocol (5/76), as can be seen in Table 4.

Our results established that the factors associated with more frequent infections were female sex $(\mathrm{p}=0.001)$, poor general condition $(\mathrm{p}<0.001)$, IIIB 3B (advanced) DurieSalmon stage of disease $(p=0.007)$, increased serum creatinine ( $p=0.036)$, neutropenia $(\mathrm{p}=0.009)$, high serum ferritin level $(p=0.001)$, and the presence of catheters, especially urinary $(p<0.001)$. There was no difference in infection occurrence related to the patient's age ( $\mathrm{p}=0.072)$, ISS score $(\mathrm{p}=0.532)$, or presence of immuneparesis $(\mathrm{p}=0.278)$.

\section{Discussion}

To date, there have been scant data regarding the incidence and characteristics of infections in hospitalised myeloma patients, especially those who were not treated with highdose therapy and HSCT. According to our results, infections occurred in $17.9 \%$ cases of myeloma patients hospitalised in our ward during a 3-year period. The most frequently isolated bacteria were Pseudomonas aeruginosa, Escherichia coli, Staphylococcus epidermidis, and Enterococcus faecalis, and the numbers of gram-positive and gram-negative infections were almost equal, which is in concordance with the existing data $[10,20]$. These agents caused mainly urinary tract infections and bacteraemia. Contrary to recent reports that showed an increased incidence of fungal infections $[12,13,14,15]$, none of these pathogens or fungal surrogate markers were detected in 
Table 1. Characteristics of tested parameters.

\begin{tabular}{|c|c|c|c|c|}
\hline \multicolumn{2}{|c|}{ Tested Parameters } & $\begin{array}{l}\text { Number } \\
\text { of Cases }\end{array}$ & $\begin{array}{l}\text { Group without } \\
\text { Infections }\end{array}$ & $\begin{array}{l}\text { Group with } \\
\text { Infections }\end{array}$ \\
\hline Sex & $\begin{array}{l}\text { Male } \\
\text { Female }\end{array}$ & $\begin{array}{l}120 \\
120\end{array}$ & $\begin{array}{l}111 \\
86\end{array}$ & $\begin{array}{l}9 \\
34\end{array}$ \\
\hline $\begin{array}{l}\text { ECOG } \\
\text { performance } \\
\text { status }\end{array}$ & $\begin{array}{l}0 \\
1 \\
2 \\
3 \\
4\end{array}$ & $\begin{array}{l}16 \\
88 \\
70 \\
45 \\
20\end{array}$ & $\begin{array}{l}16 \\
85 \\
60 \\
30 \\
5\end{array}$ & $\begin{array}{l}0 \\
3 \\
10 \\
15 \\
15\end{array}$ \\
\hline $\begin{array}{l}\text { Durie-Salmon } \\
\text { stage of } \\
\text { disease }\end{array}$ & $\begin{array}{l}1 \mathrm{~A} \\
2 \mathrm{~A} \\
2 \mathrm{~B} \\
3 \mathrm{~A} \\
3 \mathrm{~B}\end{array}$ & $\begin{array}{l}6 \\
51 \\
1 \\
106 \\
59\end{array}$ & $\begin{array}{l}5 \\
47 \\
0 \\
89 \\
40\end{array}$ & $\begin{array}{l}1 \\
4 \\
1 \\
17 \\
19\end{array}$ \\
\hline $\begin{array}{l}\text { International Staging } \\
\text { System score }\end{array}$ & $\begin{array}{l}1 \\
2 \\
3\end{array}$ & $\begin{array}{l}54 \\
57 \\
98\end{array}$ & $\begin{array}{l}44 \\
50 \\
81\end{array}$ & $\begin{array}{l}10 \\
7 \\
17\end{array}$ \\
\hline Serum creatinine level & $\begin{array}{l}\leq 100 \mathrm{mmol} / \mathrm{L}(\mathrm{f}) ; \leq 120 \mathrm{mmol} / \mathrm{L}(\mathrm{m})(\text { normal value }) \\
>100 \leq 175 \mathrm{mmol} / \mathrm{L}(\mathrm{f}) ;>120 \leq 175 \mathrm{mmol} / \mathrm{L}(\mathrm{m}) \\
>175 \mathrm{mmol} / \mathrm{f}(\mathrm{m})\end{array}$ & $\begin{array}{l}133 \\
52 \\
49\end{array}$ & $\begin{array}{l}117 \\
41 \\
35\end{array}$ & $\begin{array}{l}16 \\
11 \\
14\end{array}$ \\
\hline Immuneparesis & $\begin{array}{l}\text { Yes } \\
\text { No } \\
\text { No }\end{array}$ & $\begin{array}{l}184 \\
46 \\
160\end{array}$ & $\begin{array}{l}148 \\
40 \\
138\end{array}$ & $\begin{array}{l}36 \\
6 \\
22\end{array}$ \\
\hline Neutropenia & $\begin{array}{l}1.01-2 \times 10^{9} / \mathrm{L} \\
0.51-1 \times 10^{9} / \mathrm{L} \\
<0.5 \times 10^{9} / \mathrm{L}\end{array}$ & $\begin{array}{l}55 \\
14 \\
3\end{array}$ & $\begin{array}{l}44 \\
8 \\
1\end{array}$ & $\begin{array}{l}11 \\
6 \\
2\end{array}$ \\
\hline Serum ferritin level & $\begin{array}{l}\leq 120 \mu \mathrm{g} / \mathrm{L}(\mathrm{f}) ; \\
\leq 300 \mu \mathrm{g} / \mathrm{L}(\mathrm{m}) \\
>120 \leq 240 \mu \mathrm{g} / \mathrm{L}(\mathrm{f}) ; \\
>300 \leq 600 \mu \mathrm{g} / \mathrm{L}(\mathrm{m}) \\
>240 \mu \mathrm{g} / \mathrm{L}(\mathrm{f}) ; \\
>600 \mu \mathrm{g} / \mathrm{L}(\mathrm{m})\end{array}$ & $\begin{array}{l}51 \\
19 \\
32\end{array}$ & $\begin{array}{l}46 \\
16 \\
18\end{array}$ & $\begin{array}{l}5 \\
3 \\
14\end{array}$ \\
\hline Types of therapy & $\begin{array}{l}\text { Without therapy } \\
\text { VAD } \\
\text { MP } \\
\text { Thalidomide-based } \\
\text { Dexamethasone } \\
\text { Bortezomib-based } \\
\text { Others }\end{array}$ & $\begin{array}{l}39 \\
76 \\
13 \\
20 \\
55 \\
28 \\
5\end{array}$ & $\begin{array}{l}32 \\
71 \\
11 \\
17 \\
48 \\
14 \\
1\end{array}$ & $\begin{array}{l}7 \\
5 \\
2 \\
3 \\
7 \\
14 \\
4\end{array}$ \\
\hline $\begin{array}{l}\text { Presence of any } \\
\text { catheters }\end{array}$ & $\begin{array}{l}\text { Without catheters } \\
\text { UC } \\
\text { CVC } \\
\text { UC, CVC, ITC } \\
\text { CVC, ITC } \\
\text { UC, CVC }\end{array}$ & $\begin{array}{l}190 \\
32 \\
2 \\
2 \\
1 \\
8\end{array}$ & $\begin{array}{l}179 \\
22 \\
2 \\
0 \\
1 \\
0\end{array}$ & $\begin{array}{l}11 \\
10 \\
0 \\
2 \\
0 \\
8\end{array}$ \\
\hline
\end{tabular}

f: Female, m: male; VAD: vincristine, doxorubicin, dexamethasone, MP: oral melphalan and prednisone, UC: urinary catheter, CVC: central venous catheter, ITC: intrathoracic catheter. 
cases when fungal infection was part of a differential diagnosis $[12,13,14,15]$. This conflicting finding can be explained by the fact that our patients were not treated with high-dose therapy at the time of this study. Because of that, prolonged and severe neutropenia and mucositis, which are well-known risk factors for invasive fungal infections, occurred rarely in our group.

Traditionally, the frequency of infections is the highest during the first few months of induction therapy and in the later course of advanced disease $[9,20,21,22,23,24,25,26]$. On the contrary, patients who respond to therapy and those in the "plateau" phase are at low risk [24]. In our sample, the

Table 2. The frequencies of isolated agents.

\begin{tabular}{|c|c|}
\hline $\begin{array}{l}\text { Isolated } \\
\text { Agent }\end{array}$ & $\begin{array}{l}\text { Number of } \\
\text { Cases }\end{array}$ \\
\hline Pseudomonas aeruginosa & 9 \\
\hline Escherichia coli & 6 \\
\hline Enterococcus faecalis & 5 \\
\hline Staphylococcus epidermidis & 5 \\
\hline Proteus mirabilis & 3 \\
\hline Streptococcus sp. & 2 \\
\hline MRSA & 2 \\
\hline Staphylococcus aureus & 2 \\
\hline Streptococcus pneumoniae & 1 \\
\hline Acinetobacter & 1 \\
\hline Enterobacter & 1 \\
\hline Clostridium difficile & 1 \\
\hline
\end{tabular}

Table 3. The determined sites of infection.

\begin{tabular}{|l|l|}
\hline Sites of Infection & Number of Cases \\
\hline Urinary tract & $16(37.2 \%)$ \\
\hline Fever of unknown origin & $8(18.6)$ \\
\hline Blood (sepsis) & $7(16.3 \%)$ \\
\hline Lower respiratory tract & $3(6.9 \%)$ \\
\hline Gastrointestinal tract & $2(4.6 \%)$ \\
\hline Skin & $2(4.6 \%)$ \\
\hline Sepsis and urine & $2(4.6 \%)$ \\
\hline Sepsis and upper respiratory tract & $2(4.6 \%)$ \\
\hline Upper respiratory tract & $1(2.3 \%)$ \\
\hline Total & $43(100 \%)$ \\
\hline
\end{tabular}

average disease duration in the cases without infections was significantly shorter than in the cases with infections, which implies that infections tend to occur in the later stage of relapsed or refractory disease. This result supports the idea that uncontrolled and long-lasting myeloma increases cumulative immunosuppression and represents an important infection risk factor. Moreover, these patients more often suffer from renal failure, neutropenia, bone fractures, neuropathy, and other established infection promoters. Our results suggest that these subsets of patients are also candidates for antimicrobial prophylaxis, just as the patients during the first months of induction therapy, which has been proposed by some other researchers [27,28].

The data regarding the mortality rate in myeloma patients who contract infective complications are quite limited. Considering the fact that a significant number of our patients suffered from progressive disease, poor performance status, and high incidence of bacteraemia, the mortality rate of $9.3 \%$ seems acceptable.

Anderson et al. reported a significant proportion of infections after the VAD regimen, which was probably related to dexamethasone-induced T-cell immunodeficiency [29]. Thalidomide is not heavily myelotoxic and the infection risk is not too high when it is used. However, the incidences of infections and pneumonia are higher in MPT than in MP groups of patients in some (but not all) clinical studies, which can be related to the immunomodulatory functions and indirect effects on deep vein thrombosis and peripheral neuropathy $[30,31,32,33,34,35]$. Bortezomib is also not significantly myelotoxic, but it mediates potent immunosuppressive effects on T cells, strongly connected with herpes zoster infection and other infections $[36,37,38,39,40,41]$. The infection rate in patients treated with bortezomib is variable, but Mateos et al. reported that $75 \%$ of patients treated with melphalan, prednisone, and bortezomib had at least 1 episode of infection during treatment [42]. According to our results, patients

Table 4. Frequency of infections based on type of antitumor therapy.

\begin{tabular}{l|l|}
$\begin{array}{l}\text { Types of Antitumor } \\
\text { Therapy }\end{array}$ & $\begin{array}{l}\text { Frequency of } \\
\text { Infections }\end{array}$ \\
\hline VAD & $6.6 \%(5 / 76)$ \\
\hline MP & $15.4 \%(2 / 13)$ \\
\hline DEXA & $12.7 \%(7 / 55)$ \\
\hline Thalidomide-based therapy & $15 \%(3 / 20)$ \\
\hline Bortezomib-based therapy & $50 \%(14 / 28)$ \\
\hline
\end{tabular}

VAD: Vincristine, doxorubicin, dexamethasone, MP: oral melphalan and predni sone, DEXA: dexamethasone. 
treated with the VAD regimen had the lowest infection incidence (6.6\%), but, as already mentioned, VAD was used as the first-line therapy. The frequency of infections was higher with dexamethasone-monotherapy (12.7\%) and thalidomide-based protocols (15\%), both commonly used as second-line therapies. The highest rate of infections was in the "bortezomib-based protocols" group (50\%). As explained above, bortezomib-based protocols were used in this study as salvage treatment for refractory/progressive disease in patients with severe cumulative malfunction of the immune system, which is thought to be the main reason for the highest infection rate in patients treated with bortezomib. On the other hand, no herpes zoster infection was noticed in our group at the time of study, probably because of the prophylactic use of acyclovir.

Among our cases, almost $80 \%$ of all infective complications were restricted to the female sex, which is quite an interesting result. On the other hand, some authors found a higher infection rate among men $[24,43]$. Hargreaves et al. suggested that cigarette smoking, which was more typical for men, was one of the possible explanations for this [24]. The reasons for more frequent infections in women, especially possible differences in the infection sites, and urinary catheter application among women and men should be analysed in a future study on a representative number of patients.

In our patients, the highest infection rate was observed in those with poor performance status, i.e. WHO/ECOG Groups 3 and 4. This finding was expected because this group of patients very frequently had other infection risk factors such as advanced age, progressive/uncontrolled disease, renal dysfunction, or different catheters.

No difference in infection rate was found between different ISS groups of patients, but advanced Durie-Salmon Stage IIIB 3B was significantly associated with more frequent infective complications. Contrary to some other studies $[43,44]$, this result supports the idea that large tumour burden, especially when associated with renal failure, is an important infection risk factor in myeloma patients [43,44]. Like in other groups, a positive correlation between renal dysfunction and infections was found and these patients had a significantly higher rate of infective complications [10,43,45,46,47,48,49], which should be included in the estimation of infection risk $[10,43,45,46,47,48,49]$.

In contradiction to other studies $[10,43,45,46,47,48]$, the prognostic importance of serum polyclonal immunoglobulin deficiency as a risk factor for infection was not confirmed in our sample $[10,43,45,46,47,48]$. However, the present study evaluated immuneparesis only qualitatively, not quantitatively, and the number of patients without immuneparesis was low, which could have influenced and limited our results.
Our data confirmed the well-established fact that the degree of neutropenia in haematological diseases is related to the risk of infections $[50,51]$. The majority of our cases had no neutropenia. However, patients with neutrophil counts of less than $1 \times 109 / \mathrm{L}$ had a higher infection rate. A previous randomised trial showed some benefits for severely neutropenic myeloma patients after HSCT treated with granulocyte colonystimulating factor (G-CSF) [52]. Although the prophylactic use of G-CSF in neutropenic myeloma patients is supported on an everyday basis, the question of whether prophylactic use or addition of G-CSF to broad-spectrum antibiotics in nontransplanted myeloma patients really improved their outcome is still open and requires new clinical trials.

This study has shown that patients with high serum ferritin, and especially those with levels twice the norm (caused by an underlying disease, their treatment, blood transfusions, or the infection itself), had a greater infection incidence, which some authors have already suggested, particularly in patients treated with high-dose therapy $[11,53]$. This suggests that iron overload, and especially free iron, can cause immunosuppression, probably due to the damaging of polymorphonuclear and macrophage function, $\mathrm{T}$ cell development, and facilitation of the growth of microorganisms [54].

Indwelling central venous and urinary catheters are important devices in haematological disease management but catheter-bearing patients have impaired mucosal integrity and are at significant risk of infection complications [55,56,57]. In our group, patients with different catheters, especially urinary, had an increased infection rate in comparison to those without catheters. This result highlights the importance of our decisions and estimations of possible risk and benefit regarding the implantation of different catheters. The rate of re-infections among our patients was rather high, which implies that a previous infection represents another infection risk factor.

Over the last decades we have witnessed remarkable progress in the treatment of MM, which resulted in the prolongation of survival rates. However, these accomplishments have not been achieved only because of transplant procedures and potent novel drugs, but also because of better supportive therapy including anti-infective drugs.

According to our results, female sex, advanced clinical stage and WHO/ECOG performance status, neutropenia, increased levels of serum creatinine and ferritin, presence of catheters (especially urinary), and previous infections represent infection risk factors in patients with MM. Each myeloma patient, especially those with one or more of the mentioned risk factors, should be carefully and individually studied in order to decrease the incidence and severity of infective complications using different approaches. 


\section{Conflict of Interest Statement}

The authors of this paper have no conflicts of interest, including specific financial interests, relationships, and/or affiliations relevant to the subject matter or materials included.

\section{References}

1. Rawstron AC, Davies FE, Owen RG, English A, Pratt G, Child JA, Jack AS, Morgan GJ. B-lymphocyte suppression in multiple myeloma is a reversible phenomenon specific to normal B-cell progenitors and plasma cell precursors. Br J Haematol 1998;100:176-183.

2. Mills KH, Cawley JC. Abnormal monoclonal antibodydefined helper/suppressor T-cell subpopulations in multiple myeloma: relationship to treatment and clinical stage. $\mathrm{Br} \mathrm{J}$ Haematol 1983;53:271-275.

3. Ogawara H, Handa H, Yamazaki T, Toda T, Yoshida K, Nishimoto N, Al-ma'Quol WH, Kaneko Y, Matsushima T, Tsukamoto N, Nojima Y, Matsmuto M, Sawamura M, Murakami H. High Th1/Th2 ratio in patients with multiple myeloma. Leuk Res 2005;29:135-140.

4. Brimnes MK, Svane IM, Johnsen HE. Impaired functionality and phenotypic profile of dendritic cells from patients with multiple myeloma. Clin Exp Immunol 2006;144:76-84.

5. Brown R, Murray A, Pope B, Sze DM, Gibson J, Ho PJ, Hart D, Joshua D. Either interleukin-12 or interferon-gamma can correct the dendritic cell defect induced by transforming growth factor beta in patients with myeloma. Br J Haematol 2004;125:743-748

6. Jaharian M, Watzl C, Issa Y, Altevogt P, Momburg F. Blockade of natural killer cell-mediated lysis by NCAM140 expressed on tumor cells. Int J Cancer 2007;120:2625-2634.

7. Kraut EH, Sagone AL Jr. Alternative pathway of complement in multiple myeloma. Am J Hematol 1981;11:335-345.

8. Rajkumar SV, Jacobus S, Callander N, Fonesca R, Vesole D, Williams ME, Abonour R, Siegel DS, Katz M, Greipp PR. A randomized trial of lenalidomide plus high-dose dexamethasone (RD) versus lenalidomide plus low-dose dexamethasone $(\mathrm{Rd})$ in newly diagnosed multiple myeloma. Blood 2007;110:30.

9. Kolbe K, Domkin D, Derigs HG, Bhakdi S, Huber C, Aulitzky $\mathrm{WE}$. Infectious complications during neutropenia subsequent to peripheral blood stem cell transplantation. Bone Marrow Transplant 1997;19:143-147.

10. Nucci M, Anaissie E. Infections in patients with multiple myeloma. Semin Hematol 2009;46:277-288.

11. Miceli MH, Dong L, Grazziutti ML, Fassas A, Thertulien R, Van Rhee F, Barlogie B, Anaissie EJ. Iron overload is a major risk factor for severe infection after autologous stem cell transplantation: a study of 367 myeloma patients. Bone Marrow Transplant 2006;37:857-864.
12. Fassas AB, Bolanos-Meade J, Buddharaju LN, Rapoport A, Cottler-Fox M, Chen T, Lovchik JC, Cross A, Tricot G. Cytomegalovirus infection and non-neutropenic fever after autologous stem cell transplantation: high rates of reactivation in patients with multiple myeloma and lymphoma. $\mathrm{Br} \mathrm{J}$ Haematol 2001;112:237-241.

13. Koneru B, Hough A, Fassas A, Tricot G, Desikan KR, Siegel D. Autopsy review in multiple myeloma reveals aspergillosis as a significant cause of death after high dose therapy especially with allo-transplants. Blood 1997;90(Suppl 1):353.

14. Marr KA, Carter RA, Crippa F, Wald A, Corey L. Epidemiology and outcome of mould infections in hematopoetic stem cell transplant recipients. Clin Infect Dis 2002;34:909-917.

15. Richardson PG, Sonneveld P, Schuster MW, Irwin D, Stadtmauer EA, Facon T, Harousseau JL, Ben-Yehuda D, Lonial S, Goldschmidt H, Reece D, San-Miguel JF, Bladé J, Boccadoro M, Cavenagh J, Dalton WS, Boral AL, Esseltine DL, Porter JB, Schenkein D, Anderson KC; Assessment of Proteasome Inhibition for Extending Remissions (APEX) Investigators. Bortezomib or high-dose dexamethasone for relapsed multiple myeloma. N Engl J Med 2005;352:24872498.

16. International Myeloma Working Group. Criteria for the classification of monoclonal gammopathies, multiple myeloma and related disorders: a report of the International Myeloma Working Group. Br J Haematol 2003;121:749-757.

17. Oken MM, Creech RH, Tormey DC, Horton J, Davis TE, McFadden ET, Carbone PP. Toxicity and response criteria of the Eastern Cooperative Oncology Group. Am J Clin Oncol 1982;5:649-655.

18. Durie BG, Salmon SE. A clinical staging system for multiple myeloma. Correlation of measured myeloma cell mass with presenting clinical features, response for treatment and survival. Cancer 1975;36:842-854.

19. Greipp PR, San Miguel J, Durie BG, Crowley JJ, Barlogie B, Bladé J, Boccadoro M, Child JA, Avet-Loiseau H, Kyle RA, Lahuerta JJ, Ludwig H, Morgan G, Powles R, Shimizu K, Shustik C, Sonneveld P, Tosi P, Turesson I, Westin J. International staging system for multiple myeloma. J Clin Oncol 2005;23:34123420.

20. Blade J, Rosinol L. Complications of multiple myeloma. Hematol Oncol Clin North Am 2007;21:1231-1246.

21. Perri RT, Hebbel RP, Oken MM. Influence of treatment and response status on infection risk in multiple myeloma. Am J Med 1981;71:935-940.

22. Lenhoff S, Hjorth M, Holmberg E, Turesson I, Westin J, Nielsen JL, Wislöff F, Brinch L, Carlson K, Carlsson M, Dahl IM, Gimsing P, Hippe E, Johnsen HE, Lamvik J, Löfvenberg E, Nesthus I, Rödjer S. Impact on survival of high-dose therapy 
with autologous stem cell support in patients younger than 60 years with newly diagnosed multiple myeloma: a populationbased study. Nordic Myeloma Study Group. Blood 2000;95:7-11.

23. Terpos E, Cibeira, MT, Blade J, Ludwig H. Management of complications in multiple myeloma. Semin Hematol 2009;46:176-189.

24. Hargreaves RM, Lea JR, Griffiths H, Faux JA, Holt JM, Reid C, Bunch C, Lee M, Chapel HM. Immunological factors and risk of infection in plateau phase myeloma. J Clin Pathol 1995;48:260-266.

25. Salutari P, Sica S, Laurenti L, Leone F, Chiusolo P, Piccirillo N, Micciulli G, Leone G. Incidence of sepsis after peripheral blood progenitor cells transplantation: Analysis of 86 consecutive hemato-oncological patients. Leuk Lymphoma 1998;30:193197.

26. Ludwig H, Zojer N. Supportive care in multiple myeloma. Best Pract Res Clin Haematol 2007;20:817-835.

27. Oken M, Pomeroy C, Weisdorf D, Bennett J. Prophylactic antibiotics for the prevention of early infection in multiple myeloma. Am J Med 1996;100:624-628.

28. Bucaneve G, Micozzi A, Menichetti F, Martino P, Dionisi MS, Martinelli G, Allione B, D'Antonio D, Buelli M, Nosari AM, Cilloni D, Zuffa E, Cantaffa R, Specchia G, Amadori S, Fabbiano F, Deliliers GL, Lauria F, Foà R, Del Favero A; Gruppo Italiano Malattie Ematologiche dell'Adulto (GIMEMA) Infection Program. Levofloxacin to prevent bacterial infection in patients with cancer and neutropenia. N Engl J Med 2005;353:977-987.

29. Anderson H, Scarffe JH, Lambert M, Smith DB, Chan CC, Chadwick G, McMahon A, Chang J, Crowther D, Swindell R. VAD chemotherapy--toxicity and efficacy--in patients with multiple myeloma and other lymphoid malignancies. Hematol Oncol 1987;5:213-222.

30. Facon T, Mary JY, Pégourie B, Attal M, Renaud M, Sadoun A, Voillat L, Dorvaux V, Hulin C, Lepeu G, Harousseau JL,Eschard JP, Ferrant A, Blanc M, Maloisel F, Orfeuvre H, Rossi JF, Azaïs I, Monconduit M, Collet P, Anglaret B, Yakoub-Agha I,Wetterwald M, Eghbali H, Vekemans MC, Maisonneuve H, Troncy J, Grosbois B, Doyen C, Thyss A, Jaubert J, Casassus P,Thielemans B, Bataille R; Intergroupe Francophone du Myélome (IFM) group. Dexamethasonebased regimens versus melphalan-prednisone for elderly multiple myeloma patients ineligible for high-dose therapy. Blood 2005;107:1292-1298.

31. Hernandez JM, Garcia-Sanz R, Golovano E, Blade J, FernandezCalvo J, Trujillo J, Soler JA, Gardella S, Carbonell F, Mateo G, San Miguel JF. Randomized comparison of dexamethasone combined with melphalan versus melphalan with prednisone in the treatment of elderly patients with multiple myeloma. $\mathrm{Br}$ J Haematol 2004;127:159-164.
32. Palumbo A, Bringhen S, Caravita T, Merla E, Capparella V, Callea V, Cangialosi C, Grasso M, Rossini F, Galli M, Catalano L, Zamagni E, Petrucci MT, De Stefano V, Ceccarelli M, Ambrosini MT, Avonto I, Falco P, Ciccone G, Liberati AM, Musto P, Boccadoro M. Oral melphalan and prednisone chemotherapy plus thalidomide compared with melphalan and prednisone alone in elderly patients with multiple myeloma: randomised controlled trial. Lancet 2006;367.825-831.

33. Shustik C, Belch A, Robinson S, Rubin SH, Dolan SP, Kovacs MJ, Grewal KS, Walde D, Barr R, Wilson J, Gill K, Vickars L,Rudinskas L, Sicheri DA, Wilson K, Djurfeldt M, Shepherd LE, Ding K, Meyer RM. A randomised comparison of melphalan with prednisone or dexamethasone as induction therapy and dexamethasone or observation as maintenance therapy in multiple myeloma: NCIC CTG MY.7. Br J Haematol 2007;136:203-211.

34. Facon T, Mary JY, Hulin C, Benboubker L, Attal M, Pegourie B, Renaud M, Harousseau JL, Guillerm G, Chaleteix C, Dib M, Voillat L, Maisonneuve H, Troncy J, Dorvaux V, Monconduit M, Martin C, Casassus P, Jaubert J, Jardel H, Doyen C, Kolb B, Anglaret B, Grosbois B, Yakoub-Agha I, Mathiot C, Avet-Loiseau $\mathrm{H}$; Intergroupe Francophone du Myélome. Melphalan and prednisone plus thalidomide versus melphalan and prednisone alone or reduced-intensity autologous stem cell transplantation in elderly patients with multiple myeloma (IFM 99-06): a randomised trial. Lancet 2007;370:1209-1218.

35. Barlogie B, Tricot G, Anaissie E, Shaughnessy J, Rasmussen E, van Rhee F, Fassas A, Zangari M, Hollmig K, Pineda-Roman M, Lee C, Talamo G, Thertulien R, Kiwan E, Krishna S, Fox M, CrowleyJ. Thalidomide and hematopoietic-cell transplantation for multiple myeloma. N Engl J Med 2006;354:1021-1030.

36. Uy GL, Peles S, Fisher NM, Tomasson MH, DiPersio JF, Vij R. Bortezomib prior to autologous transplant in multiple myeloma: effects in mobilization, engraftment, and markers of immune function. Biol Blood Marrow Transplant 2006;12(Suppl 1):116.

37. Blanco B, Pérez-Simón JA, Sánchez-Abarca LI, CarvajalVergara X, Mateos J, Vidriales B, López-Holgado N, Maiso P, Alberca M, Villarón E, Schenkein D, Pandiella A, San Miguel $\mathrm{J}$. Bortezomib induces selective depletion of alloreactive $\mathrm{T}$ lymphocytes and decreases the production of Thl cytokines. Blood 2006;107:3575-3583.

38. Nencioni A, Schwarzenberg K, Brauer KM, Schmidt SM, Ballestrero A, Grunebach F, Brossart P. Proteasome inhibitor bortezomib modulates TLR4-induced dendritic cell activation. Blood 2006;108:551-558.

39. Nencioni A, Garuti A, Schwarzenberg K, Cirmena G, Dal BG, Rocco I, Barbieri E, Brossart P, Patrone F, Ballestrero A. Proteasome inhibitor-induced apoptosis in human monocytederived dendritic cells. Eur J Immunol 2006;36:681-689. 
40. Sun K, Welniak LA, Panoskaltsis-Mortari A, O'Shaughnessy MJ, Liu H, Barao I, Riordan W, Sitcheran R, Wysocki C, Serody JS, Blazar BR, Sayers TJ, Murphy WJ. Inhibition of acute graft-versus-host disease with retention of graft-versustumor effects by the proteasome inhibitor bortezomib. Proc Natl Acad Sci USA 2004;101:8120-8125.

41. Hideshima T, Richardson P, Chauhan D, Palombella VJ, Elliott PJ, Adams J, Anderson KC. The proteasome inhibitor PS-341 inhibits growth, induces apoptosis, and overcomes drug resistance in human multiple myeloma cells. Cancer Res 2001;61:3071-3076.

42. Mateos MV, Hernández JM, Hernández MT, Gutiérrez NC, Palomera L, Fuertes M, Díaz-Mediavilla J, Lahuerta JJ, de la Rubia J, Terol MJ, Sureda A, Bargay J, Ribas P, de Arriba F, Alegre A, Oriol A, Carrera D, García-Laraña J, García-Sanz R, Bladé J,Prósper F, Mateo G, Esseltine DL, van de Velde H, San Miguel JF. Bortezomib plus melphalan and prednisone in elderly untreated patients with multiple myeloma: results of a multicenter phase 1/2 study. Blood 2006;108:2165-2172.

43. Cesana C, Nosari AM, Klersy C, Miqueleiz S, Rossi V, Ferrando P, Valentini M, Barbarano L, Morra E. Risk factors for the development of bacterial infections in multiple myeloma treated with two different vincristine-adriamycindexamethasone schedules. Haematologica 2003;88:10221028.

44. Isoda A, Matsumoto M, Nakahashi H, Mawatari M, Manara A, Sawamura M. Reduced risk of bacterial infection in multiple myeloma patients with VAD regimen without intermittent high-dose dexamethasone. Int J Hematol 2011;93:59-65.

45. Espersen F, Birgens HS, Hertz JB, Drivsholm A. Current patterns of bacterial infection in myelomatosis. Scand J Infect Dis $1984 ; 16: 169-173$.

46. Rayner HC, Haynes AP, Thompson JR, Russell N, Fletcher $\mathrm{J}$. Perspectives in multiple myeloma: Survival, prognostic factors and disease complications in a single centre between 1975-1988. Q J Med 1991;79:517-525.

47. Savage DG, Lindenbaum J, Garrett TJ. Biphasic pattern of bacterial infection in multiple myeloma. Ann Intern Med 1982;96:47-50.
48. Shaikh BS, Lombard RM, Appelbaum PC, Bentz MS. Changing patterns of infections in patients with multiple myeloma. Oncology 1982;39:78-82.

49. Carlson K. Melphalan $200 \mathrm{mg} / \mathrm{m}^{2}$ with blood stem cell support as first-line myeloma therapy: impact of glomerular filtration rate on engraftment, transplantation related toxicity and survival. Bone Marrow Transplant 2005;35:985-990.

50. Bodey GP, Buckley M, Sathe YS, Freireich EJ. Quantitative relationships between circulating leukocytes and infection in patients with acute leukaemia. Ann Intern Med 1966;64:328340.

51. De Rosa L, Anghel G, Pandolfi A, Riccardi M, Amodeo R, Majolino I. Hemopoietic recovery and infectious complications in breast cancer and multiple myeloma after autologous CD43+ cell-selected peripheral blood progenitor cell transplantation. Int J Hematol 2004;79:85-91.

52. Aviles A, Guzman R, Garcia EL, Talavera A, Diaz-Maqueo JC. Results of a randomized trial of granulocyte colony-stimulating factor in patients with infection and severe granulocytopenia. Anticancer Drugs 1996;7:392-397.

53. Altes A, Remacha AF, Sarda P, Sancho FJ, Sureda A, Martino R, Briones J, Brunet S, Canals C, Sierra J. Frequent severe liver iron overload after stem cell transplantation and its possible association with invasive aspergillosis. Bone Marrow Transplant 2004;34:505-509.

54. Patruta SI, Edlinger R, Sunder-Plassmann G, Hörl WH. Neutrophil impairment associated with iron therapy in hemodialysis patients with functional iron deficiency. J Am Soc Nephrol 1998;9:655-663.

55. Norgaard M, Larsson G, Pedersen G, Schonheyder HC, Sorensen HT. Risk of bacteraemia and mortality in patients with haematological malignancies. Clin Microbiol Infect 2006;12:217-223

56. Winton EF, Langston AA. Update in acute leukaemia 2003: a risk adapted approach to acute myeloblastic leukaemia in adults. Semin Oncol 2004;31:80-86.

57. Kipps TJ. Chronic lymphocytic leukaemia. Curr Opin Hematol 2000;7:223-234. 